\title{
PERLAKUAN AKUNTANSI KARBON DI INDONESIA
}

\author{
Monika Meliana Taurisianti \\ Fakultas Ekonomika dan Bisnis, Universitas Kristen Satya Wacana \\ mariaeuprashia@yahoo.com \\ Elisabeth Penti Kurniawati \\ Fakultas Ekonomika dan Bisnis, Universitas Kristen Satya Wacana \\ bet@staff.uksw.edu
}

\begin{abstract}
This research aims to understand the implementation of accounting for carbon, about how it can be measured, recognized, recorded, presentedand disclosed based on Pernyataan Standar Akuntansi (PSAK) 19, 23, 32 and 57, also the impact toward the financial ratios. The object of this study is the financial statements of an integrated timber company in Indonesia. This study has analyzed the enables account to be used to record accounting for carbon, also analyzed the impact of implementation of accounting for carbon toward the financial ratios. The results of this study are support the previous study, which intangible asset can be recognized based on PSAK 19, whereas asset and contingent liabilities can be recognized based on PSAK 57. This study also fit out the previous study, which a company can recognize its expense and other income based on PSAK 19, 23 and 32 as a basis for forestry accounting in Indonesia.
\end{abstract}

Keywords: environmental accounting, carbon accounting

\section{PENDAHULUAN}

Indonesia merupakan negara yang memiliki sumber daya alam yang kaya, termasuk di dalamnya hutan yang sangat luas. Kementerian Kehutanan (2012) menyatakan bahwa 52,3 persen luas wilayah Indonesia merupakan hutan. Hutan di Indonesia dapat menjadi penyerap karbon yang dihasilkan oleh Indonesia sendiri maupun karbon yang dihasilkan oleh negara lain oleh karena itu Indonesia diakui sebagai paru-paru dunia. Namun demikian, Ikhsan (2008) menyatakan bahwa dalam 50 tahun terakhir tutupan hutan Indonesia berkurang dari 162 juta hektar menjadi 98 juta hektar. Hal ini disebabkan karena industri pengolahan kayu yang seringkali terkesan asal dalam melakukan penebangan. Peningkatan kerusakan lingkungan hutan ini menjadi topik yang krusial karena hutan memiliki potensi untuk menyerap karbon. 
Pada tahun 1997 pemimpin-pemimpin negara di dunia berkumpul dan menandatangani Protokol Kyoto yang ditindaklanjuti dengan penandatanganan Bali Roadmap pada tahun 2007 (UNFCCC 2012). Penandatangan Bali Roadmap menunjukkan kesungguhan berbagai negara dalam menyelesaikan permasalahan perubahan iklim, di mana salah satu langkah yang diambil adalah penerapan mekanisme biaya jasa lingkungan, termasuk mekanisme carbon trade di dalamnya.

Dalam mekanisme carbon trade, "pihak yang menghasilkan karbon akan membayar sejumlah dana sebagai kompensasi kepada pihak yang memiliki potensi menyerap karbon, sedangkan pada pihak yang memiliki potensi penyerapan karbon akan melakukan offset atas kemampuan serap karbon yang dimiliki dengan potensi karbon yang dihasilkan. Selanjutnya apabila hasil offset perusahaan memiliki surplus potensi serap karbon, maka perusahaan dapat menjual surplus potensi serap karbon tersebut ke perusahaan lain yang mengalami defisit potensi serap karbon ataupun perusahaan yang tidak memiliki potensi serap karbon. Sebaliknya, apabila hasil offset perusahaan mengalami defisit serap karbon, maka perusahaan akan membayar jasa lingkungan serap karbon kepada perusahaan yang memiliki surplus potensi serap karbon" (UNFCCC 2007).

Kemunculan kebijakan-kebijakan terkait karbon pada akhirnya berdampak terhadap akuntansi. Bagaimana pengukuran, pengakuan, pencatatan, penyajian dan pengungkapan aspek-aspek terkait karbon dilakukan menjadi kerancuan bagi para akuntan, khususnya di negara yang telah menerapkan kebijakan karbon (KPMG 2008). Pada perusahaan yang memiliki potensi serap karbon, besarnya potensi yang dimiliki akan dihitung pada awal periode pembukuan perusahaan, sehingga perusahaan akan melakukan estimasi pada awal periode atas besarnya potensi serap karbon tersebut. Selanjutnya perusahaan akan mengetahui pada akhir periode besarnya potensi karbon yang dihasilkan, lalu melakukan offset. Mekanisme pengukuran, pengakuan, pencatatan dan penyajian terkait karbon ini disebut Accounting for Carbon (KPMG 2008).

Berdasar penelitian oleh KPMG UK (2008) perusahaan-perusahaan yang beroperasi di negara yang menerapkan kebijakan carbon tax ataupun carbon trade mengalami kerancuan dalam pencatatan transaksi terkait karbon, hal ini dikarenakan sejauh ini belum terdapat standar dalam IFRS yang mengatur transaksi terkait karbon. Hariyani dan Martini (2012) menyatakan bahwa penerapan carbon accounting di Indonesia masih sulit, karena Indonesia belum memiliki standar baku dalam melakukan pengukuran karbon. Oleh sebab itu, penelitian ini mencoba melihat kemungkinan-kemungkinan perlakuan akuntansi yang diijinkan oleh PSAK apabila perusahaan menerapkan akuntansi karbon. PSAK yang digunakan sebagai acuan dalam penelitian ini adalah Pernyataan Standar Akuntansi (PSAK) yang telah mengadopsi International Financial Reporting Standards (IFRS) berdasar pada principle based. 
Penelitian ini bertujuan untuk mengetahui bagaimana pengukuran, pengakuan, pencatatan, penyajian dan pengungkapan akuntansi karbon berdasarkan PSAK, serta dampaknya terhadap rasio-rasio keuangan perusahaan. Untuk menentukan surplus/defisit serap karbon, dalam penghitungan offset atas kemampuan serap karbon yang dimiliki dengan potensi karbon yang dihasilkan, penelitian ini membatasi perhitungan kehilangan kemampuan serap karbon hanya didasarkan pada besarnya potensi serap karbon yang hilang akibat penebangan pohon saja, belum memperhitungkan kehilangan serap karbon akibat dari emisi karbon lain pada keseluruhan proses produksi.

\section{LANDASAN TEORI}

\section{Akuntansi Lingkungan (Environmental Accounting)}

Ikhsan (2008) mendefinisikan bahwa akuntansi lingkungan adalah proses menggambarkan biaya-biaya lingkungan supaya diperhatikan oleh stakeholders perusahaan yang mampu mendorong pengidentifikasian cara-cara mengurangi atau menghindari biaya-biaya ketika pada waktu yang bersamaan sedang memperbaiki kualitas lingkungan.

"Environmental accounting is the context of national income accounting refers to
natural resource accounting, which can entail statistics about a nation's or region's
consumption, extent, quality and value of natural resources, both renewable and
non-renewable. Environmental accounting in the context of financial accounting
usually refers to preparation of financial reports for external audiences using
Generally Accepted Accounting Principles. Environmental accounting as an aspect
of management accounting serves business managers in making capital investment
decisions, costing determinations, process/product design decisions, performance
evaluations and a host of other forward-looking business decisions")(U.S. EPA 1995,
dalam Ikhsan 2009).

Akuntansi berwawasan lingkungan atau akuntansi hijau mencoba memasukkan nilai-nilai kearifan lingkungan dalam pencatatan akuntansi. Pengakuan nilai-nilai kearifan lingkungan dalam laporan keuangan didasarkan pada beberapa konsep berikut ini.

Provisi (Kewajiban Diestimasi), provission is a liability of uncertain timing or amount (sometimes referred to as an estimated liability) (Kieso, Weygandt, Warfield 2011), sedangkan menurut PSAK 57 (2009), provisi merupakan liabilitas yang waktu dan jumlahnya belum pasti.

Pendapatan, yaitu arus masuk bruto dari manfaat ekonomi yang timbul dari aktivitas normal perusahaan apabila arus masuk mengakibatkan kenaikan ekuitas yang tidak timbul dari kontribusi penanaman modal (PSAK 23, 2009). Dyckman, Dukes \& Davis (2004) menyatakan bahwa berdasar dari sumber pendapatan, akuntansi mengenal dua jenis pendapatan. Pertama adalaha pendapatan operasional, yaitu pendapatan yang diperoleh dari usaha pokok perusahaan, yaitu penjualan 
barang dan/atau pemberian jasa yang bersifat rutin, yang kedua adalah pendapatan non operasional yaitu pendapatan yang diperoleh perusahaan di luar usaha pokok. Secara spesifik PSAK 23 (2009) mendefinisikan pendapatan operasional pada perusahaan kehutanan sebagai pendapatan dari penjualan hasil hutan, baik berupa olahan kayu, hasil tebangan, maupun hasil hutan lainnya.

Biaya adalah pengorbanan sumber ekonomi yang diukur dalam satuan uang, yang telah terjadi atau yang mungkin akan terjadi untuk tujuan tertentu, sehingga biaya dalam arti luas diartikan sebagai pengorbanan sumber ekonomi untuk memperoleh aktiva (IAI, 2009). Biaya adalah kas atau nilai ekuivalen kas yang dikorbankan untuk mendapat barang atau jasa yang diharapkan memberikan manfaat saat ini atau di masa yang akan datang bagi organisasi (Hansen \& Mowen 2006).

Beban, oleh Sinamora (1995) sebagai biaya yang terpakai (expired cost), sedangkan dalam kerangka dasar penyusunan dan penyajian laporan keuangan (PSAK, 2007) beban didefinisikan sebagai penurunan manfaat ekonomi selama suatu periode akuntansi dalam bentuk arus keluar atau berkurangnya aset atau terjadinya kewajiban yang mengakibatkan penurunan ekuitas yang tidak menyangkut pembagian kepada penanam modal. Sementara itu terkait beban-beban pada perusahaan kehutanan, PSAK 32 (2007) tentang akuntansi kehutanan menyatakan bahwa: harga pokok produksi kayu tebangan dan hasil hutan lainnya meliputi beban yang terjadi dalam hubungannya dengan kegiatan-kegiatan seperti perencanaan, penanaman, pemeliharaan dan pembinaan hutan, pengendalian kebakaran dan pengamanan hutan, pemungutan hasil hutan, pemenuhan kewajiban terhadap negara, pemenuhan kewajiban lingkungan dan sosial, serta pembangunan sarana dan prasarana. Pada Hutan Tanaman Industri (HTI), beban umum dan administrasi yang tidak berkaitan dengan kegiatan penanaman, pemeliharaan dan pembinaan hutan dibukukan sebagai beban umum dan administrasi.

Aset tak berwujud adalah aktiva tak lancar (non current asset) dan tak berbentuk yang memberikan hak keekonomian dan hukum kepada pemiliknya dan dalam laporan keuangan tidak dicakup secara terpisah dalam klasifikasi aktiva yang lain (PSAK 19 2010). Aset kontijensi adalah aset potensial yang timbul dari peristiwa masa lalu dan keberadaannya menjadi pasti dengan terjadi atau tidak terjadinya satu peristiwa atau lebih pada masa depan yang tidak sepenuhnya berada dalam kendali perusahaan. (PSAK 57 2009).

\section{Akuntansi Karbon (CarbonAccounting)}

Akuntansi karbon merupakan akuntansi yang memasukkan aspek-aspek terkait karbon ke dalam laporan keuangan perusahaan. Saat ini terdapat satu standar pengukuran karbon yang diakui oleh The United Nations Framework Convention on Climate Change (UNFCCC), yaitu National Carbon Accounting Standards (NCAS) yang merupakan standar nasional yang dimiliki oleh Australia. Dalam akuntansi karbon terdapat beberapa teori yang mendasari, yaitu: carbon accounting is the process by which organizations account for and report on their greenhouse gas 
emissions (Prosser 2013). Sehingga dapat diartikan bahwa carbon accounting adalah suatu proses pengukuran dan pelaporan terkait emiten (karbon) yang dihasilkan oleh suatu perusahaan. Exit Price Accounting, Palea (2013) menjelaskan bahwa Exit Price Acounting adalah gabungan konsep dari Chambers (1966,1975), Sterling (1970) dan MacNeal (1970) yang mengukur aset dengan nilai realisasi atas penjualan aset tersebut dengan harga jual yang berlaku pada umumnya. Exit Price Accounting merupakan salah satu metoda pengukuran yang diungkapkan oleh Edwards dan Bells (1961) dalam Zeff (2010) yaitu sistem yang menggunakan harga jual pasar khusus untuk mengukur posisi keuangan perusahaan dan kinerja keuangan. Metoda ini dipilih karena PSAK 57 menyatakan bahwa provisi ataupun aset kontijensi harus dapat diestimasi secara andal, oleh karena itu dalam melakukan estimasi digunakan harga pasar terbaru atas karbon.

Berdasar konsep-konsep di atas, penelitian ini mencoba membuat kerangka teoritis dalam penghitungan besarnya kemampuan serap karbon atas kepemilikan pohon, potensi serap karbon yang hilang akibat penebangan pohon, dimana potensi karbon yang hilang akan diakui sebagai emiten yang muncul akibat kegiatan operasional perusahaan yang pada akhirnya proses offset atas kepemilikan potensi serap karbon serta karbon yang dihasilkan (emiten akibat penebangan pohon) diukur, diakui, dicatat, disajikan dan diungkapkan dengan beberapa alternatif sebagaimana dimungkinkan dengan berdasar pada PSAK.

Pada penelitian ini perlakuan akuntansi terkait karbon akan dibahas dari sudut pandang perusahaan yang memiliki kapasitas penyerapan karbon yang akan melakukan offset pada akhir periode, sehingga terdapat dua kemungkinan pencatatan yaitu, pada kondisi surplus atau defisit potensi serap karbon. Pada penelitian ini, harga jual pasar yang digunakan adalah nilai tukar carbon terhadap satuan moneter (USD) yang berlaku dalam Carbon Trading. Carbon Trading atau sering diartikan sebagai perdagangan karbon dapat didefinisikan sebagai menjual kemampuan pohon yang dapat menyerap karbondioksida dalam rangka menekan keberadaan karbon dioksida itu sendiri di atmosfer untuk mengurangi pemanasan global (Razak 2008). Nalar konsep penelitian ini dapat digambarkan pada Gambar 1.

Nalar konsep tersebut dapat dijelaskan sebagai berikut. Akuntansi konvensional menekankan pada pencatatan transaksi atas kegiatan operasional perusahaan. Pada perkembangannya, akuntansi mulai memasukkan unsur-unsur lingkungan ke dalam pencatatan laporan keuangan. Terkait dengan adanya perdagangan karbon, akuntansi mulai mencatat transaksi-transaksi terkait karbon sesuai dengan prinsip akuntansi yang berlaku di masing-masing negara, yang sering disebut carbon accounting. 


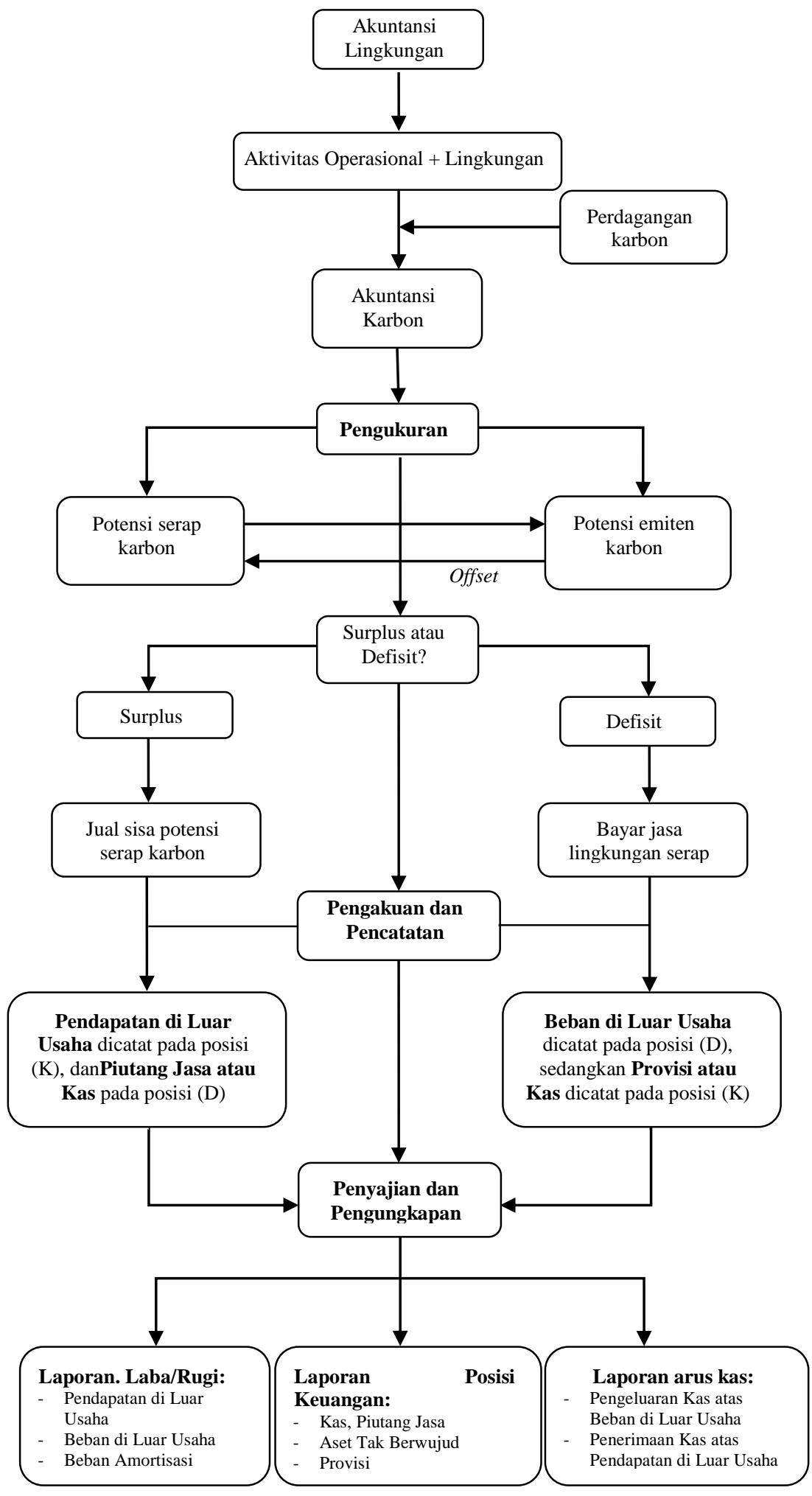

Gambar 1

Nalar Konsep Penelitian 
Dalam mengukur nilai aspek-aspek terkait karbon, terlebih dahulu dihitung nilai surplus atau defisit karbon, dengan melakukan offset antara potensi serap karbon dengan emiten karbon yang dihasilkan. Proses offset adalah proses saling hapus (PSAK 55) yang biasa digunakan dalam penghitungan aset derivatif dan tanggungan. Dalam hal ini kewajiban yang dimiliki akan dikurangi aset yang dimiliki. Untuk mengakui dan mencatat transaksi-transaksi terkait karbon, digunakan akun-akun pendapatan di luar usaha, beban di luar usaha, aset tak berwujud dan provisi. Selanjutnya akun-akun yang telah diakui akan disajikan dalam laporan keuangan perusahaan. Akun pendapatan di luar usaha dan beban di luar usaha akan disajikan pada laporan Laba/Rugi, sedangkan akun aset tak berwujud dan provisi akan disajikan pada laporan posisi keuangan perusahaan.

\section{METODA PENELITIAN}

Penelitian ini merupakan penelitian studi kasus yang digunakan untuk membantu pemahaman perlakuan akuntansi karbon dalam sebuah perusahaan, khususnya pada perusahaan sektor kehutanan di Indonesia. Objek penelitian ini adalah Laporan Keuangan Konsolidasian PT Dharma Satya Nusantara, Tbk Tahun 2013. Perusahaan ini resmi beroperasi secara komersial sejak April 1985 dan bergerak di bidang industri perkayuan terpadu, tanaman perkebunan dan agro. Pada tahun 2012, perseroan mengadakan kerjasama guna memperoleh hak guna atas areal lahan seluas 1.770 hektar (Laporan Keuangan Konsolidasian 2013 PT Dharma Satya Nusantara, Tbk).

Jenis data yang digunakan dalam penelitian ini adalah data sekunder, yaitu: data kandungan karbon hutan jati (Tim Perubahan Iklim Badan Litbang Kehutanan 2010), data nilai tukar pasar karbon pada program carbon trading (Siikamäki, Sanchirico \& Jardinec 2012), data nilai kurs tengah Bank Indonesia (www.bi.go.id per 21 Januari 2014) dan laporan keuangan PT Dharma Satya Nusantara, Tbk tahun 2013 (http://dsn.co.id). Keuangan PT DSN digunakan sebagai dasar ilustrasi perhitungan rasio jika perusahaan tersebut menerapkan akuntansi karbon.

Langkah-langkah analisis dalam penelitian ini dilakukan sebagai berikut, pertama melakukan pengukuran akuntansi karbon dengan dua skenario, yaitu surplus dan defisit; kedua, menganalisis kemungkinan-kemungkinan pengakuan, pencatatan, penyajian dan pengungkapan akuntansi karbon dengan mengacu pada PSAK 19,23,32,57. Setelah itu menganalisis dampak akuntansi karbon terhadap rasio keuangan perusahaan. 


\section{PEMBAHASAN}

\section{Pengukuran}

Pengukuran akuntansi karbon dilakukan dengan beberapa langkah. Pertama, mengukur kandungan karbon pertegakan pohon berdasar kelompok usia. Dalam melakukan pengukuran besarnya aspek-aspek karbon, besarnya kemampuan pohon yang dimiliki perusahaan dalam menyerap karbon perlu diketahui. Kemampuan pohon dalam menyerap karbon ini selanjutnya akan digunakan sebagai dasar untuk mengakui besarnya kemampuan penyerapan karbon yang hilang saat pohon tersebut ditebang. Perhitungan akuntansi karbon sebaiknya disesuaikan dengan karakteristik tanaman yang dikelola perusahaan dengan mengaitkannya dengan data cadangan karbon pada berbagai tipe hutan dan jenis tanaman, yang dalam penelitian ini menggunakan hasil riset Tim Perubahan Iklim Badan Litbang Kehutanan. Pengakuan dan pencatatan aset tak berwujud untuk tanaman yang bertumbuh dari tahun ke tahun dapat disesuaikan perhitungan potensi serap karbonnya sesuai usia tanaman. Dengan asumsi seluruh lahan perusahaan ditanami pohon jati, data yang digunakan sebagai acuan berdasarkan data cadangan karbon pada berbagai tipe hutan dan jenis tanaman di Indonesia hasil riset Tim Perubahan Iklim Badan Litbang Kehutanan yang tersaji dalam Tabel 1.

Tabel 1

Kandungan Karbon Hutan Jati (Kg/Ha)

\begin{tabular}{ccc}
\hline $\begin{array}{c}\text { Umur pohon } \\
\text { (Tahun) }\end{array}$ & $\begin{array}{c}\text { Jumlah pohon/Ha } \\
\text { (Batang) }\end{array}$ & $\begin{array}{c}\text { Kandungan karbon/Ha } \\
(\mathrm{Kg} \mathrm{C} / \mathrm{Ha})\end{array}$ \\
\hline 1 & 3.818 & $5.408,50$ \\
10 & 913 & $41.137,10$ \\
20 & 482 & $61.533,80$ \\
30 & 324 & $76.066,30$ \\
40 & 243 & $87.897,50$ \\
50 & 195 & $98.631,20$ \\
60 & 164 & $109.092,50$ \\
70 & 142 & $119.077,10$ \\
80 & 127 & $130.160,20$ \\
\hline
\end{tabular}

Sumber: Tim Perubahan Iklim Badan Litbang Kehutanan, Desember 2010, Carbon Stocks on Various Type of Forest and Vegetation in Indonesia, Pusat Penelitian dan Pengembangan Perubahan Iklim dan Kebijakan, Bogor.

Kedua, menetapkan asumsi mengenai harga pasar perdagangan emisi. Setelah mengetahui besarnya kemampuan penyerapan karbon yang hilang akibat penebangan pohon jati, maka langkah berikutnya adalah menetapkan asumsi harga pasar perdagangan emisi. Langkah ini dilakukan karena harga pasar perdagangan emisi akan digunakan untuk mengonversi besarnya potensi penyerapan karbon yang hilang ke dalam satuan moneter. Dalam penelitian ini harga yang digunakan adalah harga pasar hak emisi pada perdagangan emisi sebesar USD10/ton (Walhi 2007).

Ketiga, menetapkan asumsi kurs yang digunakan. Setelah mendapatkan nilai karbon yang telah dikonversi dalam satuan moneter pada langkah kedua, maka 
langkah selanjutnya adalah menetapkan asumsi kurs rupiah terhadap USD yang akan digunakan. Hal ini dilakukan, mengingat nilai moneter yang didapat pada langkah kedua masih dalam satuan moneter USD, karena itu perlu untuk dikonversi ke dalam satuan moneter rupiah. Dalam menetapkan asumsi kurs rupiah terhadap USD, kurs yang digunakan pada penelitian ini adalah kurs tengah Bank Indonesia dengan nominal Rp12.122,00 (www.bi.go.id, per 21 Januari 2014).

Keempat, menetapkan usulan formula penghitungan akuntansi karbon. Berdasar penjelasan-penjelasan di atas, maka dalam menghitung aspek-aspek terkait karbon, dilakukan penghitungan dengan usulan formula sebagai berikut:

$Y=\left(\sum\left(\mathrm{n} x_{1} \times \alpha x_{1}\right)+\left(n x_{i} \times \alpha x_{i}\right)\right) \times p \times b$

Keterangan:

$\mathrm{Y}=$ Provisi

$\mathrm{n} x_{i}=$ Jumlah pohon kategori usia

$\alpha x_{i}=$ Nilai kemampuan serap karbon pohon kategori usia

$\mathrm{p}=$ Harga pasar karbon

$\mathrm{b}=$ Kurs terkini

Langkah-langkah yang telah dilakukan di atas pada akhirnya akan menghasilkan suatu nilai dengan satuan moneter rupiah yang selanjutnya akan diakui dan disajikan dalam laporan keuangan perusahaan.

Agar lebih jelas dalam pengaplikasian langkah-langkah yang telah dijelaskan di atas, maka akan diilustrasikan sebuah studi kasus pengukuran estimasi potensi serap karbon menggunakan data lahan milik PT Dharma Satya Nusantara, Tbk seluas 1.770 Ha (Lampiran 1), dengan asumsi seluruh lahan ditanami pohon jati dengan dua kategori usia rata-rata umur tegakan pohon 10 tahun seluas 1.000 hektar dan 770 hektar dengan perkiraan rata-rata umur tegakan pohon 30 tahun. Pada pengukuran ini, terdapat dua skenario.

Pada skenario pertama (surplus), apabila bulan ini perusahaan sudah mengelola hutan dengan menebang pohon seluas 200 hektar untuk kategori tegakan berusia sepuluh tahun dan 300 hektar untuk kategori tegakan berusia 30 tahun. Maka untuk dapat menentukan besarnya biaya lingkungan akan digunakan model penghitungan: (jumlah hektar yang sudah dikelola $\mathrm{x}$ jumlah cadangan karbon) $\mathrm{x}$ harga pasar emisi x nilai kurs USD-IDR. Menghitung nilai kepemilikan potensi serap karbon

$Y=\left(\sum\left(\mathrm{n} x_{1} \times \alpha x_{1}\right)+\left(n x_{i} \times \alpha x_{i}\right)\right) \times p \times b$

$\mathrm{Y}=((1000 \mathrm{Ha} \times 41.137,1 \mathrm{KgC} / \mathrm{Ha})+(770 \mathrm{Ha} \times 76.066,3 \mathrm{KgC} / \mathrm{Ha})) \times 0,01 \mathrm{USD} \times \mathrm{Rp} 12.122,00$

$\mathrm{Y}=99.708 .151 \mathrm{KgC} \times 0,01 \mathrm{USD} \times \mathrm{Rp} 12.122,00$

$\mathrm{Y}=\mathrm{Rp} 12.086 .622 .060,00$

Total nilai kepemilikan potensi serap karbon $=\mathrm{Rp} 12.086 .622 .060,00$

Mengitung nilai emiten karbon yang dihasilkan karena penebangan pohon

$Y=\left(\sum\left(\mathrm{n} x_{1} \times \alpha x_{1}\right)+\left(n x_{i} \times \alpha x_{i}\right)\right) \times p \times b$

$\mathrm{Y}=((200 \mathrm{Ha} \times 41.137,1 \mathrm{KgC} / \mathrm{Ha})+(300 \mathrm{Ha} \times 76.066,3 \mathrm{KgC} / \mathrm{Ha})) \times$ 0,01USD $\times \mathrm{Rp} 12.122,00$ 
$\mathrm{Y}=31.047 .310 \mathrm{KgC} \times 0,01 \mathrm{USD} \times \mathrm{Rp} 12.122,00$

$\mathrm{Y}=\mathrm{Rp3} .763 .554 .918,00$

Total nilai emiten karbon $=\mathrm{Rp} 3.763 .554 .918,00$

Menghitung offset potensi serap karbon dengan emiten karbon

Surplus potensi serap karbon $=$ potensi serap karbon - emiten karbon dihasilkan

Surplus potensi serap karbon $=$ Rp12.086.622.060,00 - Rp3.763.554.918,00

Surplus potensi serap karbon $=$ Rp8.325.067.148,00

Pada skenario kedua (defisit), diasumsikan perusahaan telah melakukan pengelolaan dengan menebang pohon pada seluruh lahan yang dimiliki dan perusahaan telah menghitung emiten karbon yang muncul akibat proses penebangan sebesar Rp2.000.000.000,00. Maka perusahaan akan melakukan penghitungan aspekaspek karbon sebagai berikut. Menghitung nilai kepemilikan potensi serap karbon

$Y=\left(\sum\left(\mathrm{n} x_{1} \times \alpha x_{1}\right)+\left(n x_{i} \times \alpha x_{i}\right)\right) \times p \times b$

$\mathrm{Y}=((1000 \mathrm{Ha} \times 41.137,1 \mathrm{KgC} / \mathrm{Ha})+(770 \mathrm{Ha} \times 76.066,3 \mathrm{KgC} / \mathrm{Ha})) \times$ 0,01USD $\times \mathrm{Rp} 12.122,00$

$\mathrm{Y}=99.708 .151 \mathrm{KgC} \times 0,01 \mathrm{USD} \times \mathrm{Rp} 12.122,00$

$\mathrm{Y}=\mathrm{Rp} 12.086 .622 .060,00$

Total nilai kepemilikan potensi serap karbon $=\mathrm{Rp} 12.086 .622 .060,00$

Mengitung nilai emiten karbon yang dihasilkan karena penebangan pohon

$Y=\left(\sum\left(\mathrm{n} x_{1} \times \alpha x_{1}\right)+\left(n x_{i} \times \alpha x_{i}\right)\right) \times p \times b$

$\mathrm{Y}=((1000 \mathrm{Ha} \times 41.137,1 \mathrm{KgC} / \mathrm{Ha})+(770 \mathrm{Ha} \times 76.066,3 \mathrm{KgC} / \mathrm{Ha})) \times$ 0,01 USD x Rp12.122,00

$\mathrm{Y}=99.708 .151 \mathrm{KgC} \times 0,01 \mathrm{USD} \times \mathrm{Rp} 12.122,00$

$\mathrm{Y}=\mathrm{Rp} 12.086 .622 .060,00$

Total nilai emiten karbon $=\mathrm{Rp} 12.086 .622 .060,00+\mathrm{Rp} 2.000 .000 .000,00$

Total nilai emiten karbon $=\mathrm{Rp} 14.086 .622 .060,00$

Menghitung offset potensi serap karbon dengan emiten karbon

Defisit potensi serap karbon $=$ potensi serap karbon - emiten karnon dihasilkan

Defisit potensi serap karbon $=$ Rp12.086.622.060,00 - Rp14.086.622.060,00

Defisit potensi serap karbon $=(\operatorname{Rp} 2.000 .000 .000,00)$

Metoda penghitungan konversi nilai karbon ke nilai moneter yang diajukan dalam penelitian ini menggunakan dasar nilai pasar karbon yang berlaku saat pengukuran dilakukan, prinsip ini terdapat dalam metoda pengukuran Current Cost Accounting, khususnya dengan model pengukuran Current Purchase Exchange. Current Cost Accounting Method adalah konsep akuntansi yang menyatakan pos-pos laporan keuangan dinilai dengan harga perolehan sekarang, yaitu dengan harga perolehan yang mempunyai umur dan kapasitas yang sama (Edwards \& Bell 1961 dalam Zeff 2010). Sedangkan Current Purchase Exchange adalah model pengukuran menggunakan harga pertukaran pembelian sekarang. Dengan menggunakan metoda 
pengukuran Current Cost Accounting, maka nilai yang dihasilkan akan lebih relevan, karena selalu disesuaikan dengan harga pasar terkini dari emisi karbon. Sehingga, nilai kewajiban lingkungan yang dihitung besarnya cukup memadai untuk mewakili kewajiban yang terjadi saat itu.

\section{Pengakuan dan Pencatatan}

Potensi penyerapan karbon yang dimiliki oleh perusahaan dapat diakui sebagai aset tak berwujud, sesuai kriteria aset tak berwujud dalam PSAK 19 (2010), lebih spesifik lagi dapat dikategorikan dalam indefinitive intangible asset. Pengakuan ini didasari oleh kriteria definitive intangible asset dalam PSAK 19 (2010), yang harus diamortisasi sesuai masa manfaatnya, diuji penurunan nilai apabila terdapat indikasi penurunan nilai. Kriteria-kriteria tersebut dapat terpenuhi oleh daya serap pohon atas karbon, dimana daya serap pohon memiliki umur yang sama dengan lama pohon ditanam sebelum mencapai masa tebang dan nilai daya serap pohon harus diuji setiap tahun karena ada pohon yang ditebang selama proses produksi.

Perusahaan dapat mengakui kepemilikan potensi serap karbon sebagai aset tak berwujud, dengan melakukan pencatatan sebagai berikut:

$$
\begin{array}{ll}
\text { Aset Tak Berwujud } & \text { Rp12.086.622.060,00 } \\
\text { Modal } & \text { Rp12.086.622.060,00 }
\end{array}
$$

Selain itu, perusahaan juga dapat mengakui kepemilikan potensi serap karbon sebagai aset diestimasi. Sebagaimana terdapat pada PSAK 57 (2009), aset diestimasi tidak dicantumkan dalam laporan keuangan, maka perusahaan tidak melakukan pencatatan apapun pada laporan keuangan perusahaan. Jika kemudian perusahaan melakukan penebangan pohon sehingga mengakibatkan potensi serap karbon berkurang, maka perusahaan akan melakukan penyesuaian atas nilai aset tak berwujud sesuai dengan besarnya surplus atau defisit potensi serap karbon yang dimilikinya.

Pada kasus penghitungan skenario pertama, di mana perusahaan mengalami surplus potensi serap karbon, perusahaan akan melakukan penyesuaian atas nilai aset tak berwujud sesuai dengan besarnya surplus potensi serap karbon yang dimilikinya sebagai berikut:

$$
\begin{array}{ll}
\text { Pengurangan Emiten } & \text { Rp3.763.554.918,00 } \\
\text { Aset Tak Berwujud } & \text { Rp3.763.554.918,00 }
\end{array}
$$

Dengan demikian, saat ini Aset Tak Berwujud perusahaan senilai Rp8.325.067.148,00. Dalam kondisi surplus potensi serap karbon, perusahaan dapat menjual potensi serap karbon tersebut kepada pihak lain, sehingga perusahaan dapat mengakui pendapatan di luar usaha (PSAK 23, 2010). Perusahaan dapat melakukan pencatatan sebagai berikut: 
Piutang Jasa Lingkungan atau Kas

Pendapatan Jasa Lingkungan (di Luar Usaha)
Rp8.325.067.148,00

$\operatorname{Rp} 8.325 .067 .148,00$

Sedangkan pada skenario kedua, dimana perusahaan mengalami defisit potensi serap karbon, perusahaan akan melakukan penyesuaian atas nilai aset tak berwujud sesuai dengan besarnya defisit potensi serap karbon yang dimilikinya sebagai berikut:

$$
\begin{array}{ll}
\text { Pengurangan Emiten } & \text { Rp14.086.622.060,00 } \\
\text { Aset Tak Berwujud } & \text { Rp14.086.622.060,00 }
\end{array}
$$

Dengan demikian, saat ini Aset Tak Berwujud perusahaan senilai (Rp2.000.000.000,00), sehingga dapat dikatakan perusahaan sudah tidak memiliki Aset Tak Berwujud lagi. Dalam kondisi defisit potensi serap karbon, perusahaan harus membayar biaya jasa lingkungan. Perusahaan dapat mengakui beban diluar usaha (PSAK 23 2010) atau beban lingkungan dan sosial (PSAK 32 2007) atas pembayaran jasa lingkungan tersebut dan dicatat pada sisi debit, sedangkan pada sisi kredit perusahaan dapat mengakui kewajiban diestimasi apabila pada awal periode perusahaan sudah melakukan estimasi defisit potensi serap karbon, atau kas apabila penghitungan dilakukan pada awal periode dan kekurangan dibayar tunai.

Akuntansi mengenal dua macam kewajiban, yaitu kewajiban lancar dan kewajiban tidak lancar. Di dalam masing-masing kewajiban lancar dan kewajiban tidak lancar, apabila dibagi berdasarkan kepastian keterjadian maka dapat dibagi menjadi kewajiban pasti dan kewajiban tidak pasti. Kewajiban tidak pasti terdiri dari provisi dan kontijensi. Aspek-aspek terkait karbon yang dihitung sebelumnya, tidak dikategorikan sebagai kewajiban pasti karena kewajiban pasti biasanya berhubungan dengan kewajiban kepada pihak perbankan, vendor, ataupun pihak lain yang berhubungan langsung dengan operasional perusahaan di mana nilai serta waktu jatuh tempo pembayaran kewajiban tersebut sudah jelas. Sedangkan kewajiban karbon yang diestimasi, waktu jatuh tempo pembayaran belum jelas, meskipun besarnya nilai yang menjadi kewajiban perusahaan sudah dapat diestimasi. Oleh karena itu, pencatatan tersebut dapat dilakukan sebagai berikut:

$$
\begin{array}{ll}
\text { Biaya Jasa Lingkungan (Di Luar Usaha) } & \text { Rp2.000.000.000,00 } \\
\text { Provisi (Kewajiban Diestimasi) atau Kas } & \text { Rp2.000.000.000,00 }
\end{array}
$$

Pada dasarnya akuntansi membagi kewajiban tidak pasti menjadi dua. Yang pertama adalah provisi. Provission is a liability of uncertain timing or amount (sometimes referred to as an estimated liability) (Kieso, Weygandt, Warfield 2011), menurut PSAK 57, provisi merupakan liabilitas yang waktu dan jumlahnya belum pasti. Kedua adalah Kewajiban Kontijensi. Menurut PSAK 57 Revisi 2009: kewajiban potensial yang timbul dari masa lalu dan keberadaannya menjadi pasti dengan terjadi atau tidak terjadinya satu peristiwa atau lebih pada masa datang yang 
tidak sepenuhnya berada dalam kendali entitas, atau kewajiban kini yang timbul sebagai akibat peristiwa masa lalu, tetapi tidak diakui karena: tidak terdapat kemungkinan entitas mengeluarkan sumber daya yang mengandung manfaat ekonomi untuk menyelesaikan kewajibannya atau jumlah kewajiban tersebut tidak dapat diukur secara andal.

Berdasar kriteria-kriteria yang ada di atas, maka aspek-aspek karbon lebih tepat diakui sebagai provisi karena waktu keterjadian atau waktu jatuh tempo pembayaran belum pasti, meskipun jumlah kewajiban dapat diestimasi secara andal. Sedangkan untuk mengkategorikan kewajiban ini termasuk kewajiban lancar atau kewajiban tidak lancar, lebih tepat untuk diakui sebagai kewajiban lancar. Karena kewajiban ini dihitung per tahun, yang nantinya pada akhir periode akan di-offset dengan kepemilikan perusahaan atas potensi serap karbon.

Potensi serap karbon akan ada selama tanaman belum ditebang. Oleh karena itu, penurunan nilai atas aset tak berwujud terjadi apabila terdapat indikasi penurunan kemampuan serap karbon akibat penebangan pohon maupun kerusakan hutan lainnya. Daya serap pohon atas karbon memiliki umur yang sama dengan lama pohon ditanam sebelum mencapai masa tebang. Oleh karena itu, dalam perhitungan amortisasi, dapat menggunakan masa manfaat dengan asumsi lamanya pohon akan di tanam. Karena kemampuan serap karbon berbeda-beda sesuai jenis dan usia pohon, maka cost driver dalam perhitungan beban amortisasi dapat menggunakan jumlah pohon yang ditebang dengan memperhatikan jenis dan usia pohon.

\section{Penyajian}

Dalam laporan posisi keuangan, aset akan disajikan pada sisi debit dan kewajiban akan muncul pada posisi kredit. Sesuai PSAK 57 (2009), pengakuan atas aset kontijensi tidak disajikan pada laporan keuangan, sedangkan aset tak berwujud akan dicatat pada posisi debit laporan posisi keuangan. Penyajian aset pada laporan posisi keuangan akan dibedakan menjadi aset lancar dan tidak lancar. Aset tak berwujud akan disajikan dalam aset tidak lancar, penyajian atas aset tak berwujud yang diakui perusahaan, diatur oleh PSAK 19 (2010). Aset tak berwujud ini selanjutnya akan diamortisasi, hingga habis masa manfaatnya.

Penyajian kewajiban akan dibedakan dengan kriteria jangka waktu jatuh tempo menjadi kewajiban lancar dan kewajiban tidak lancar. Apabila melihat kepastian keterjadian, sebagaimana diatur oleh PSAK 57 (2009) maka ada perbedaan penyajian dalam laporan keuangan. Kewajiban yang besar kemungkinan keterjadiannya diatas 50 persen atau biasa kita sebut dengan istilah provisi, harus disajikan dalam neraca seperti kewajiban pada umumnya. Sedangkan untuk kewajiban yang kemungkinan keterjadiannya rendah dan nilainya sulit diestimasi dengan andal yang sering kita kenal sebagai kewajiban kontijensi dalam penyajiannya tidak perlu ditampilkan dalam neraca, cukup hanya diberikan catatan kaki dalam Catatan Atas Laporan Keuangan (CALK). 
Aspek-aspek terkait karbon yang selanjutnya diakui sebagai kewajiban provisi jangka pendek, akan disajikan dalam akun kewajiban lancar. Kewajiban provinsi ini harus dicatat dan dilaporkan penuh sebesar nilai jatuh tempo yang telah diestimasi (PSAK 57 2009) dan karena jangka waktu jatuh tempo yang tergolong singkat (kurang dari 12 bulan) maka perbedaan nilai estimasi sekarang dan nilai jatuh temponya biasanya tidak akan terlalu besar.

Akun kewajiban lancar biasanya disajikan sebagai klasifikasi pertama dalam kelompok kewajiban dan ekuitas pemegang saham di neraca (sisi kredit dalam neraca). Dalam penyajiannya, akun-akun kewajiban lancar dapat disajikan urut menurut waktu jatuh temponya, nomor akunnya, atau besar nilai kewajiban tersebut.

\section{Pengungkapan}

PSAK mengatur pengungkapan kewajiban diestimasi dan aset diestimasi serta asset tak berwujud sebagai berikut. Pertama adalah kewajiban diestimasi dan aset diestimasi. PSAK 57 (2009) mewajibkan untuk setiap jenis kewajiban diestimasi, termasuk provisi, entitas harus mengungkapkan: "Nilai tercatat pada awal dan akhir periode, kewajiban diestimasi tambahan yang dibuat dalam periode bersangkutan, termasuk peningkatan jumlah pada kewajiban diestimasi yang ada, jumlah yang digunakan, yaitu jumlah yang terjadi dan dibebankan pada kewajiban diestimasi selama periode bersangkutan, jumlah yang belum digunakan atau dibatalkan selama periode yang bersangkutan, peningkatan, selama periode yang bersangkutan, dalam nilai kini yang timbul karena berlalunya waktu dan dampak dari setiap perubahan tingkat diskonto tidak diharuskan. Selain hal-hal di atas, perusahaan harus mengungkapkan pula: uraian singkat mengenai karakteristik kewajiban dan perkiraan saat arus keluar sumber daya terjadi, indikasi mengenai ketidakpastian saat atau jumlah arus keluar tersebut jika diperlukan dalam rangka menyediakan informasi yang memadai, perusahaan harus mengungkapkan asumsi utama yang mendasari prakiraan peristiwa masa depan sebagaimana diatur dalam paragraf 50 dan jumlah estimasi penggantian yang akan diterima dengan menyebutkan jumlah aset yang telah diakui untuk estimasi penggantian tersebut." Sedangkan untuk aset diestimasi, PSAK 57 tidak mengatur mengenai pengungkapannya.

Kedua adalah aset tak berwujud, PSAK 19 (2010) mengharuskan entitas mengungkapkan hal-hal berikut untuk setiap kelas aset tak berwujud, dipisahkan antara aset tak berwujud yang dihasilkan secara internal dan aset tak berwujud lainnya. Berdasarkan uraian di atas, alternatif-alternatif pengakuan, pencatatan, penyajian dan pengungkapan transaksi terkait karbon beserta dasar acuannya secara singkat disajikan dalam Tabel 2. 
Tabel 2

Perlakuan Pengukuran, Pengakuan, Pencatatan, Penyajian dan PengungkapanTransaksi Karbon

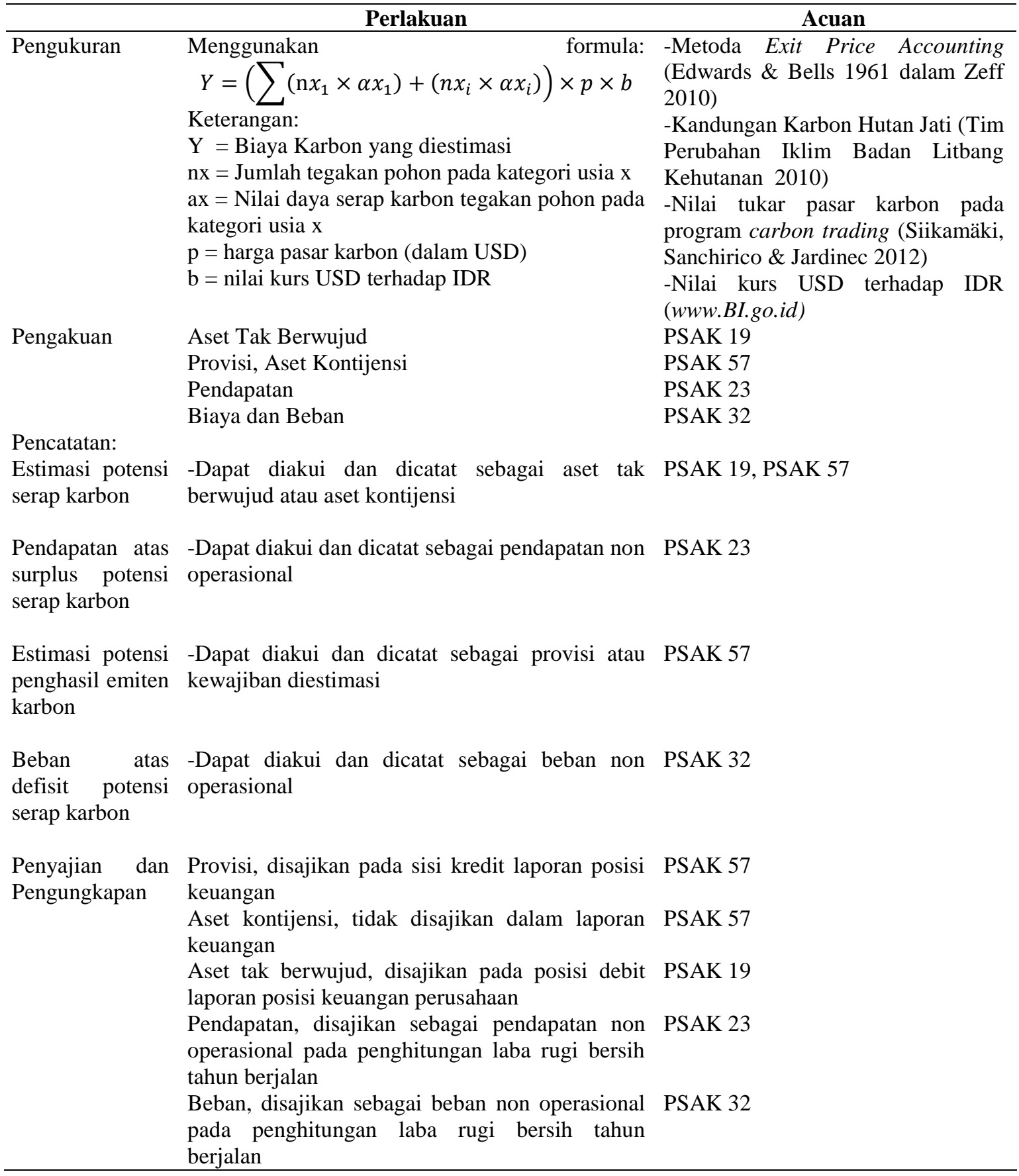

\section{Dampak terhadap Rasio Keuangan}

Dengan adanya perlakuan akuntansi terkait karbon tersebut tentunya akan berdampak terhadap performa laporan keuangan serta rasio keuangan perusahaan. Laporan posisi keuangan mencerminkan persamaan akuntansi: aset $=$ liabilitas + ekuitas, di mana jumlah pada sisi aset (debit), harus sama dengan jumlah pada sisi liabilitas + ekuitas (kredit). Sehingga apabila dalam laporan posisi keuangan ada 
tambahan komponen provisi pada sisi kredit (liabilitas), maka akan terjadi perubahan nilai atas ekuitas pada sisi kredit karena jumlah liabilitas ditambah ekuitas harus seimbang dengan jumlah aset. Penurunan ekuitas sendiri terjadi karena akuntansi menganut matching principle dimana beban akan diakui pada saat produk secara aktual memberikan kontribusi terhadap pendapatan. Sehingga beban karbon akan dimasukkan ke dalam komponen penyusun laporan laba/rugi. Tambahan beban ini, tentunya akan berdampak terhadap penurunan laba perusahaan, yang mana laba ini nanti akan mempengaruhi besarnya nilai ekuitas akhir yang tercantum pada laporan posisi keuangan perusahaan. Karena laba yang dihasilkan turun, maka nilai ekuitas akan turun.

Adanya tambahan akun provisi lancar, mengakibatkan nilai liabilitas lancar meningkat sehingga berdampak pada turunnya nilai rasio likuiditas. Hal ini dikarenakan dalam menghitung current ratio, quick ratio maupun cash ratio, besar nilai liabilitas lancar akan digunakan sebagai pembagi sehingga apabila nilai pembagi meningkat, maka nilai rasio akan turun.

Selain berdampak terhadap rasio likuiditas, perubahan nilai liabilitas pada laporan posisi keuangan juga akan berdampak terhadap nilai rasio solvabilitas. Rasio solvabilitas dapat dihitung dengan membagi total liabilitas dengan total aset, sehingga apabila terjadi peningkatan nilai total liabilitas yang tertera pada sisi kredit laporan posisi keuangan, maka hasil penghitungan rasio solvabilitas akan meningkat. Namun di sisi lain, karena aset tak berwujud meningkat maka apabila jumlah penghitungan aset lebih besar dari biaya emiten karbon maka ratio solvabilitas akan turun.

Selain dua rasio yang sudah dibahas di atas, kita juga mengenal rasio rentabilitas. Rasio ini dihitung dengan membagi laba perusahaan dengan penjualan. Pembebanan biaya lingkungan dalam laporan laba/rugi perusahaan akan menghasilkan laba yang lebih kecil, sehingga rasio rentabilitas mengalami penurunan.

Hasil analisis akuntansi karbon beserta pembuktian penghitungan rasio-rasio keuangan secara singkat dapat dilihat pada Tabel 3. 
Tabel 3

Analisa Dampak Akuntansi Karbon terhadap Rasio Keuangan

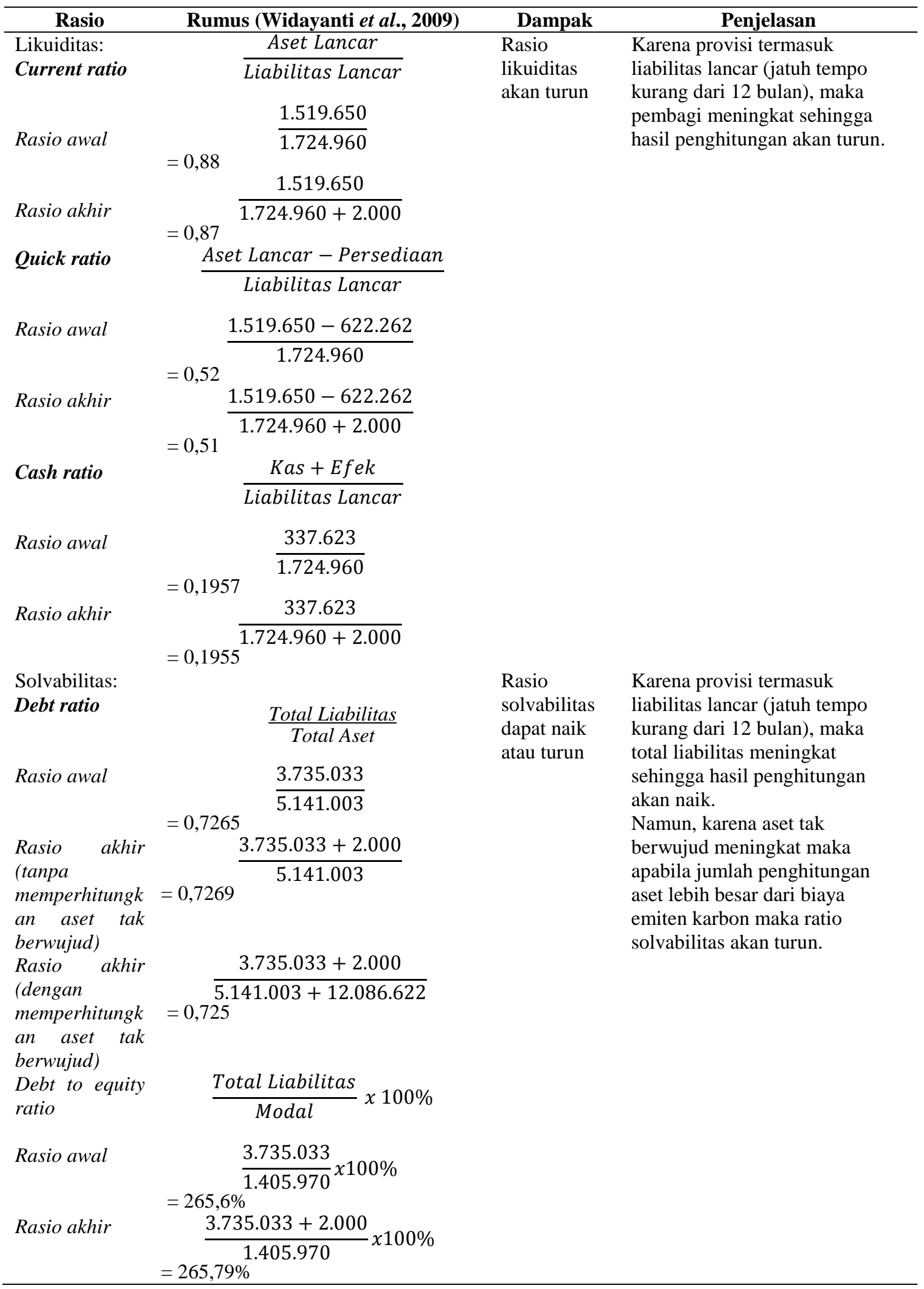


Tabel 3 (Lanjutan)

Analisa Dampak Akuntansi Karbon terhadap Rasio Keuangan

\begin{tabular}{|c|c|c|c|}
\hline Rasio & Rumus (Widayanti et al., 2009) & Dampak & Penjelasan \\
\hline Rentabilitas: & & Rasio & Karena terdapat pengakuan \\
\hline \multirow[t]{2}{*}{ Profit margin } & Laba Kotor & rentabilitas & beban di luar usaha pada periode \\
\hline & Penjualan & akan turun & berjalan maka saldo laba pada \\
\hline \multirow[t]{4}{*}{ Rasio awal } & 738.176 & & $\begin{array}{l}\text { laporan laba rugi mengalami } \\
\text { penurunan, sehingga nilai laba }\end{array}$ \\
\hline & $\overline{2.564 .592}$ & & kotor turun dan nilai rasio \\
\hline & $=0,2878$ & & rentabilitas juga turun. \\
\hline & $738.176-2.000$ & & \\
\hline Rasio akhir & 2.564 .592 & & \\
\hline
\end{tabular}

\section{SIMPULAN DAN IMPLIKASI}

Penerapan akuntansi karbon dapat dilakukan dengan mengestimasi besar kewajiban yang menjadi tanggung jawab perusahaan atas kerusakan lingkungan akibat kegiatan operasional perusahaan, khususnya karbon. Estimasi kewajiban ini dapat dilakukan dengan menggunakan metoda exit price accounting, sehingga nilai kewajiban yang menjadi tanggung jawab perusahaan akan terus mengikuti perkembangan nilai karbon yang ada di pasar.

Pengakuan kepemilikan potensi serap karbon dapat diakui sebagai akun aset tak berwujud atau aset kontijensi, yang pencatatan dan pengungkapannya masingmasing diatur dalam PSAK 19 (2010) dan PSAK 57 (2009). Pengakuan terkait pembayaran biaya jasa lingkungan dapat diakui sebagai beban di luar usaha, atau beban lingkungan dan sosial, yang pencatatan dan pengungkapannya diatur dalam PSAK 23 (2010) dan PSAK 32 (2007). Pengakuan pendapatan atas surplus potensi serap karbon dapat diakui sebagai pendapatan di luar usaha, yang pencatatan dan pengungkapannya diatur dalam PSAK 23 (2010) atau PSAK 32 (2007). Sedangkan untuk perusahaan yang melakukan estimasi biaya jasa lingkungan sejak awal periode dapat mengakui sebagai provisi, yang pencatatan dan pengungkapannya diatur dalam PSAK 57 (2009). Pengakuan akun-akun tersebut pada akhirnya akan berdampak pada kinerja laporan keuangan yang tercermin pada rasio-rasio keuangan, seperti rasio solvabilitas, likuiditas dan rentabilitas. Pada penelitian ini rasio likuiditas dan rentabilitas perusahaan mengalami penurunan, sedangkan rasio solvabilitas dapat mengalami peningkatan atau penurunan.

Sebagai implikasi dari pengakuan aspek-aspek karbon tersebut maka perusahaan dapat mengakui kewajiban tersebut sebagai provisi, beban di luar usaha, pendapatan di luar usaha, aset tak berwujud, ataupun aset kontijensi. Pengakuan ini berdasar pada PSAK 19, 23, 32, 57. Pengakuan-pengakuan atas aset kontijensi, aset tak berwujud dan provisi mendukung hasil penelitian KPMG (2008) yang menyatakan kemungkinan pencatatan sebagai akun-akun tersebut berdasarkan IAS 37 dan 38. 


\section{KETERBATASAN PENELITIAN DAN PENELITIAN MENDATANG}

Penelitian ini terbatas pada perlakuan akuntansi karbon pada perusahaan di bidang kehutanan. Selain itu, hasil penelitian ini masih sebatas pada pemahaman bagaimana mengestimasi biaya karbon serta bagaimana pengakuan dan dampaknya terhadap rasio keuangan apabila perusahaan hendak menerapkan pencadangan dana perbaikan lingkungan akibat karbon. Penelitian ini belum menghitung besar potensi beban karbon lain secara keseluruhan dan kemungkinan-kemungkinan kecurangan (fraud) yang dapat terjadi apabila kebijakan akuntansi karbon diterapkan.

Besarnya kerugian/beban potensial yang ditanggung oleh perusahaan sebenarnya dapat menjadi penanding penghitungan biaya karbon dalam penelitian ini, yang dapat digunakan sebagai bahan pertimbangan manajemen untuk menentukan kebijakan mana yang sebaiknya diambil, apakah hendak mencadangkan provisi atau tidak. Apabila keduanya dapat diestimasi dengan baik, maka manajemen dapat mengetahui kemungkinan arus kas keluar di masa mendatang dan membandingkannya dengan arus kas keluar pada provisi. Oleh karena itu, hasil penelitian ini belum dapat digunakan sebagai bahan pertimbangan manajemen dalam pengambilan keputusan tersebut, namun sekadar memberikan gambaran tentang cara mengestimasi perhitungan dalam akuntansi karbon.

Oleh karena itu, penelitian mendatang dapat menggunakan objek perusahaan kehutanan dan non kehutanan, menghitung besar potensi beban karbon lain secara keseluruhan, menentukan alternatif metoda amortisasi yang tepat atas pengakuan aset tak berwujud dan menganalisis kemungkinan-kemungkinan kecurangan (fraud) yang dapat terjadi apabila kebijakan akuntansi karbon diterapkan di Indonesia. 


\section{Lampiran 1}

Catatan Atas Laporan Keuangan PT Dharma Satya Nusantara TBK

(http://dsn.co.id/uploads)

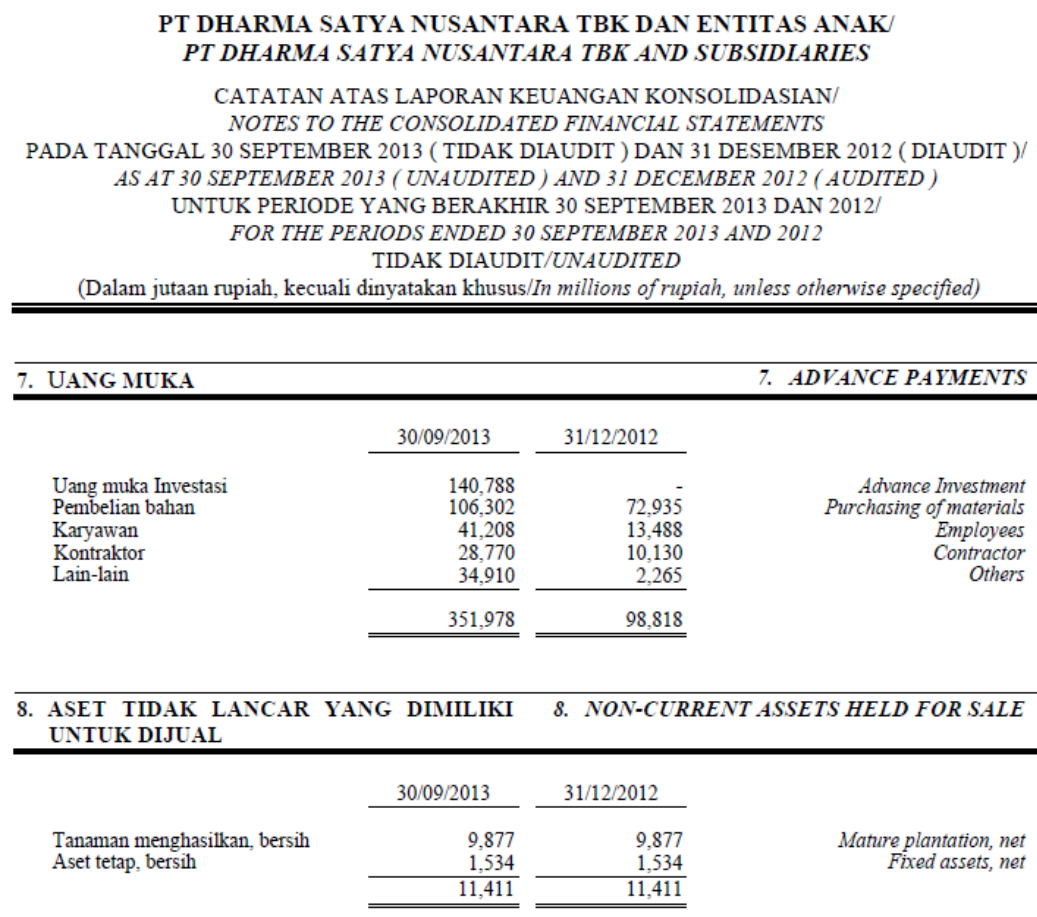

Pada tanggal 28 Mei 2012, SWA mengadakan perjaniian dengan penusahaan-perucahaan pertambanga dibawah grup BEP (PT Persada Multi Bara PT Khazana Bumi Kaliman dan PT Bumi Kaliman Sejahtera) untuk menyerahkan sebagian dari hak at tanah ("Hak Guna Usaha"/HGU) SWA dengan tota area 1.770 hektar berlokasi di Desa Benhes Dabeq Diah Lay, Kecamatan Muara Wahau, Kabupate Kutai, Propinsi Kalimantan Timur beserta tanaman perkebunan dan fasilitas-fasilitas yang terdapat didalamnya dengan total kompensasi Rp 189.390.

Tanah seluas 1.770 hektar termasuk tanaman perkebunan dan fasilitas-fasilitas yang terdapat didalamnya dengan nilai tercatat sebesar $R p 11.41$ disajikan sebagai aset dimiliki untuk dijual sehubungan dengan komitmen penjualan seperti yang disebutkan diatas.

Tanggal efektif penyerahan tanah, tanaman perkebunan dan fasilitas-fasilitas adalah sembilan bulan setela tanggal perjanjian. SWA telah menerima uang muka dari perusahaan-perusahaan pertambangan senilai Rp 36.466 dan dicatat sebagai uang muka penjualan aset tidak lancar yang dimiliki untuk diju
dalam liabilitas jangka pendek lainnya (Catatan 16).

On 28 May 2012, SWA entered into agreements with mining companies under BEP group (PT Persada Multi Bara, PT Khazana Bumi Kaliman and PT Bumi Kaliman Sejahtera) to release part of SWA land rights ("Hak Guna Usaha"/HGU) with area totaling 1,770 hectare located at the village of Benhes Dabeq Diah Lay, District of Muara Wahau, Kutai Regency, Eas Kalimantan Province as well the plantation and facilities on the land with total compensation of Rp 189,390.

Land area of 1,770 hectare including the plantation and its facilities on the land with carrying amount of $R p 11,411$ is presented as assets held for sale following SWA selling commitments as mentioned above.

The effective date to release the lands, plantation and facilities is nime months after the agreements date SWA has received advances from the mining companies totaling $R p \quad 36,466$ and recorded as advance from sales of non-current assets held for sale under other current liabilities (Note 16). 


\section{Lampiran 2}

Laporan Laba/Rugi PT Dharma Satya Nusantara

(http://dsn.co.id/uploads)

\begin{tabular}{|c|c|c|c|c|}
\hline \multicolumn{5}{|c|}{ PT DHARMA SATYA NUSANTARA TBK DAN ENTITAS ANAK/ } \\
\hline \multicolumn{5}{|c|}{$\begin{array}{c}\text { LAPORAN LABA RUGI KOMPREHENSIF KONSOLIDASIAN/ } \\
\text { CONSOLIDATED STATEMENTS OF COMPREHENSIVE INCOME } \\
\text { UNTUK PERIODE YANG BERAKHIR 30 SEPTEMBER } 2013 \text { DAN 2012/ } \\
\text { FOR THE PERIODS ENDED } 30 \text { SEPTEMBER } 2013 \text { AND } 2012 \\
\text { TIDAK DIAUDIT/UNAUDITED } \\
\text { (Dalam jutaan rupiah, kecuali dinyatak an khusus/In millions of nupiah, unless otherwise specified) }\end{array}$} \\
\hline & $\begin{array}{c}\text { Catatan/ } \\
\text { Notes } \\
\end{array}$ & $30 / 09 / 2013$ & $30 / 09 / 2012$ & \\
\hline PENJUALAN BERSIH & $2 c, 24$ & $2,681,431$ & $2,564,592$ & NET S.ALES \\
\hline BEBAN POKOK PENJUALAN & $2 \mathrm{~d} .25$ & $(1,942,540)$ & $(1,826,416)$ & COST OF SALES \\
\hline LABA BRUTO & & 738.891 & 738,176 & GROSS PROFIT \\
\hline Pendapatan lainnya & 26 & $\begin{array}{r}2.905 \\
(158,106)\end{array}$ & $\begin{array}{r}11,871 \\
(148,372)\end{array}$ & $\begin{array}{r}\text { Other income } \\
\text { Selling expenses }\end{array}$ \\
\hline Beban umam dan administrasi & 27 & $(180,196)$ & $(184,856)$ & General and administrativeexpenses \\
\hline $\begin{array}{l}\text { penghapusan aset tetap } \\
\text { Beban lainnya }\end{array}$ & & $\begin{array}{r}457 \\
(12,605) \\
\end{array}$ & $\begin{array}{r}1,562 \\
(30,504) \\
\end{array}$ & $\begin{array}{l}\text { Gain (loss) on sace and alsposati } \\
\text { of frued assets } \\
\text { Other expenses }\end{array}$ \\
\hline LABA USAHA & & 391,346 & 387,877 & OPERATING PROFIT \\
\hline Biaya keuangan & 25,28 & $(230,115)$ & $(114,753)$ & Finance costs \\
\hline Pendapatan keungan & 25 & 7.631 & 4.878 & Finance income \\
\hline $\begin{array}{l}\text { LABA SEBELUM PAJAK } \\
\text { PENGHASILAN }\end{array}$ & & 168,862 & 278,002 & $\begin{array}{l}\text { PROFIT BEFORE } \\
\text { INCOME TAX }\end{array}$ \\
\hline Beban pajak penghasilan & $2 n, 18 b$ & $(45,573)$ & $(83,886)$ & Incame tax expense \\
\hline $\begin{array}{l}\text { LABATOTAL LABA } \\
\text { KOMPREHENSIF TAHUN } \\
\text { BERJALAN }\end{array}$ & & 123,289 & 194,116 & $\begin{array}{l}\text { PROFIT/TOTAL } \\
\text { COMPREHENSIVE INCOME } \\
\text { FOR THE YEAR }\end{array}$ \\
\hline $\begin{array}{l}\text { LABATOTAL LABA } \\
\text { KOMPREHENSIF YANG DAPAT } \\
\text { DLATRIBUSIKAN KFPADA: }\end{array}$ & & & & $\begin{array}{l}\text { PROFIT/TOTAL } \\
\text { COMPREHENSIVE INCOMEE } \\
\text { ATTRIBUTABLE TO: }\end{array}$ \\
\hline Pemilike entitas indulk & & 112,265 & 165,313 & Owners of the Company \\
\hline Kepentingan non-pengendali & & $\frac{11,024}{123,289}$ & $\frac{28,803}{194,116}$ & Non-controilling interests \\
\hline $\begin{array}{l}\text { LABA PER SAHAM } \\
\text { (Rupiah penuh) }\end{array}$ & & & & $\begin{array}{l}\text { EARNINGS PER SHARE } \\
\text { (whole Rupiah) }\end{array}$ \\
\hline $\begin{array}{l}\text { Dasar, laba tahun berjalan yang dapat } \\
\text { diatribusiskan kepada pernilik entatas } \\
\text { induluk }\end{array}$ & $2 p .28$ & 57.50 & 109.59 & $\begin{array}{l}\text { Baric, profit for the your } \\
\text { attributable to owners of } \\
\text { the Campary }\end{array}$ \\
\hline
\end{tabular}

Lihat Catatan atas Laporan Keuangan Konsolidasian yang See Notes to the Consolidatod Financial Statements, which
merupakan bagian tal terpisalkan dari laporan keuangan form an integral part of these consolidated financial merupakan bagsan. statements. 
Lampiran 3

Laporan Posisi Keuangan PT Dharma Satya Nusantara (http://dsn.co.id/uploads)

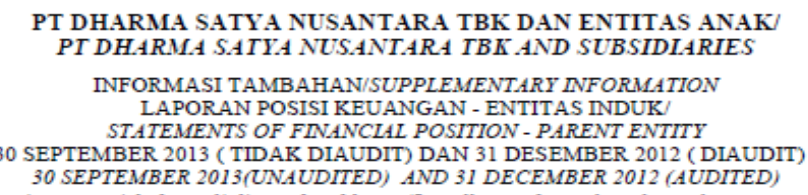

Informasi keuangan tambahan PT Dhanna Satya Nusantara The following supplementary financial information of (entitas induk saja) berikut ini tidak termasul saldo dari PT Dharrma Satya Nusantara (parent entity), which entitas anak, dan telah disusun dan disajikan dengan excluded balances of subsidiaries, has been prepared and menggunakan kebijakan akuntansi yang konsisten dengan presented using the accounting policies that are consistent yang diterapkan pada laporan keuangan konsolidasian with those appited to the consolidated financial statements Perseroan dan entitas anak, kecuali untulk investasi pada of the Company and subsidiaries, except for investments in entitas anak dan entitas asosiasi, yang disajikan sebesar subsidiaries and associates, which have been presented a biaya peroleban cost

ASET

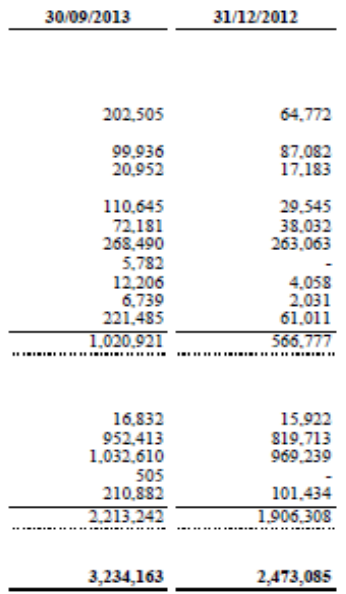

ASSETS

Aset Lancar

Kas
Piutang usaha

Pihak ketiga

Piutang lain-lain
Phank ketiga

Phak berelas
Persedian bersih

Pajak penghasilan dibayar dimuk

Pajuk pertambahan nilui dibsyar dinak a

Beban dibayar dimul

Total Aset Lancar

Aset Tidalk Lancar

Asset pajak tangguhan, bersih

Investasi jangka panjang

Biaya akuisisi tanah ditangguhla

Total Aset Tidak Lancar

$3,234,163$

$2,473,085$

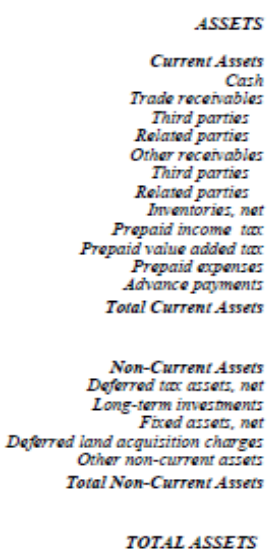




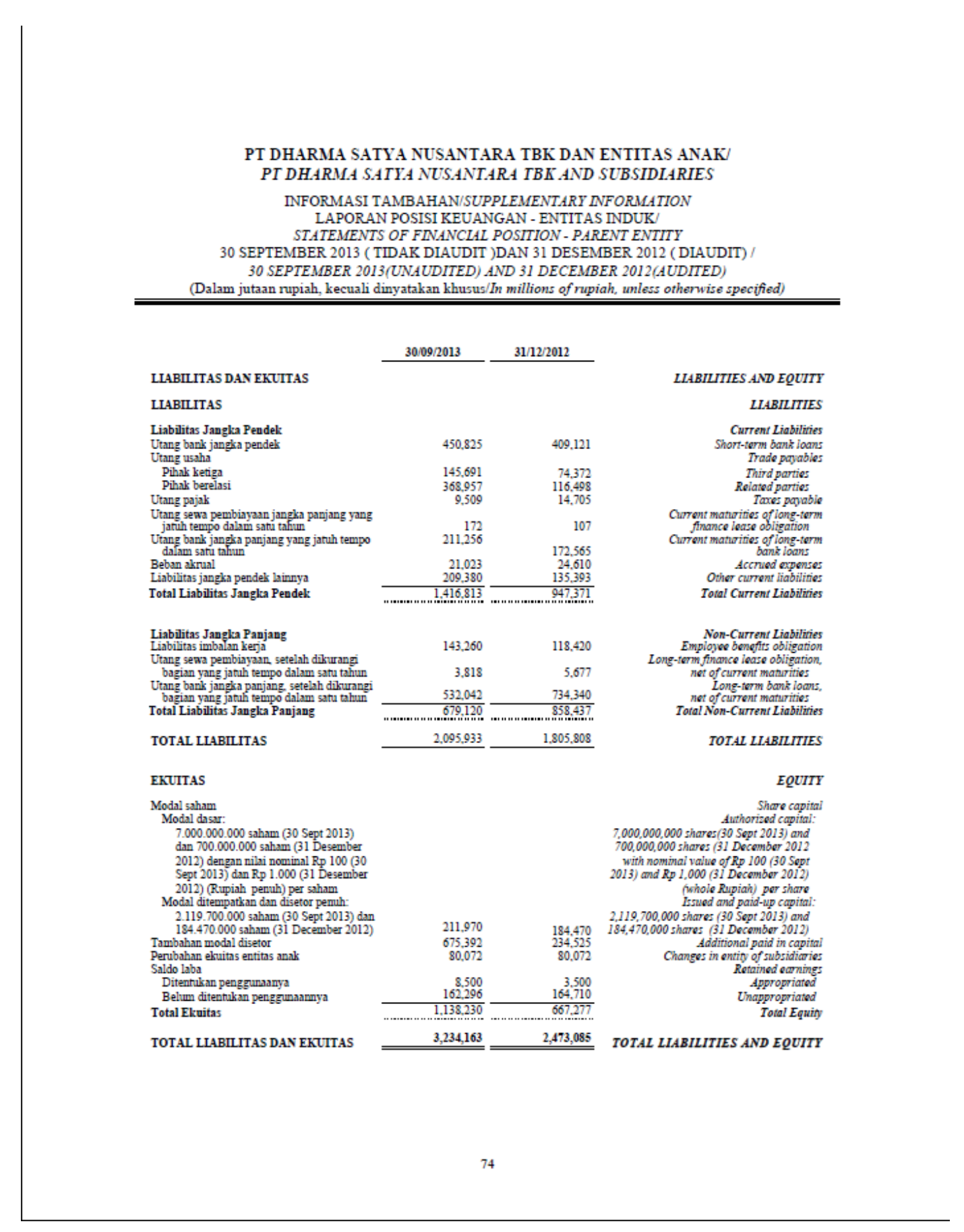




\section{DAFTAR PUSTAKA}

Dyckman, T. R., R. E. Dukes, dan C. J. Davis. 2004. Intermediate Accounting. New York: The Mc Graw Hill Companies Inc. Available at http://ebookily.net.

Hansen, D. R., dan M. M. Mowen. 2006. Managerial Accounting. Ohio: International Thompson Publishing Co. Available at http://books.google.co.id.

Hariyani, R., dan Martini. 2012. Implementasi carbon accounting di indonesia dan kendala, permasalahan, solusi (PT Indocement, Tbk). Fakultas Ekonomi, Universitas Budi Luhur Jakarta. Available at http://portal.kopertis3.or.id.

Ikatan Akuntan Indonesia. 2009. PSAK 2007. Jakarta: Salemba Empat.

Ikatan Akuntan Indonesia. 2009. PSAK No.19 Revisi 2010. DSAK Jakarta: Salemba Empat.

Ikatan Akuntan Indonesia. 2009. PSAK No.23 Revisi 2010. DSAK Jakarta: Salemba Empat.

Ikatan Akuntan Indonesia. 2009. PSAK No.32 Revisi 2010. DSAK Jakarta: Salemba Empat.

Ikatan Akuntan Indonesia. 2009. PSAK No.57 Revisi 2009. DSAK Jakarta: Salemba Empat.

Ikhsan, A. 2008. Akuntansi Lingkungan dan Pengungkapannya. Jakarta: Graha Ilmu.

Ikhsan, A. 2009. Akuntansi Manajemen Lingkungan. Jakarta: Graha Ilmu.

Kementerian Kehutanan. 2012. Buku Statistik Kehutanan Indonesia Kementerian Kehutanan 2011. Available at http://wwf.indonesia.go.id.

Kieso, D. E., J. J. Weygandt, dan T. D. Warfield. 2011. Intermediate Accounting: IFRS Edition. United States: John Wiley \& Sons, Inc. Available at http://www.google.co.id/books.

KPMG. 2008. Accounting for carbon, the impact of carbon trading on finanial statements. United Kingdom, KPMG. Available at http://www.kpmg.no.

Palea, V. 2013. Fair value accounting and it's usefulness to financial statement users. Department of Economics and Statistics COGNETTI DE MARTIIS Italy. Available at $h t t p: / / w w w$. unito.it.

Prosser, A. 2013. Carbon accounting and reporting the disclosure and reporting of carbon emissions in a growing trend for both investors and customers. UK, Verco. Available at http://www.vercoglobal.com.

Razak, A. 2008. Kajian yuridis carbon trade dalam penyelesaian efek rumah kaca. Program Studi Manajemen Konservasi Sumber Daya Alam dan Lingkungan, UGM Yogyakarta. Available at http://heterometrus.files.wordpress.com. 
Siikamäki, J., J. N. Sanchirico, dan S. L. Jardinec. 2012. Global economic potential for reducing carbon dioxide emissions from mangrove loss. Proceedings of the National Academy of Sciences 109: 14369-14374.

Sinamora, H. 1995. Akuntansi Manajemen. Jakarta: Salemba Empat.

Tim Perubahan Iklim Badan Litbang Kehutanan. 2010. Carbon stocks on various type of forest and vegetation in indonesia. Pusat Penelitian dan Pengembangan Perubahan Iklim dan Kebijakan, Bogor. Available at http://www.forda_mof.org.

UNFCCC. 2012. Kyoto protocol. Available at http://UNFCCC.int/kyoto_protocol.

UNFCCC. 2007. The kyoto protocol mechanism international emissions trading clean development menchanism joint implementation. UNFCCC Germany. Available at http://UNFCCC.int/resource/docs/publications/mechanisms.

Wahana Lingkungan Hidup (WALHI). 2007. Perdagangan karbon, bali. Available at http://walhibali.blogspot.com.

Widayanti, R. 2009. Manajemen Keuangan. Fakultas Ekonomi UKSW Salatiga.

Zeff, S. A. 2010. Insights from Accounting History. New York: Sage Publication. Available at http://books.google.co.id/book. 